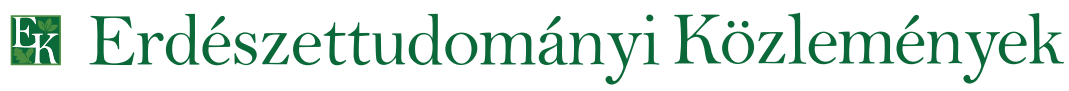

DOI: https://doi.org/10.17164/EK.2021.005

11. évfolyam 1-2. szám 2021

131-142. oldal

\section{MIKROORGANIZMUSOK SZEREPE A SZÚBOGARAK (CURCULIONIDAE, SCOLYTINAE) ÖKOLÓGIÁJÁBAN}

\author{
Balázs Balázs Gábor, Tuba Katalin és Lakatos Ferenc \\ Soproni Egyetem, Erdőmérnöki Kar, Erdő- és Természeti Erőforrás-gazdálkodási Intézet
}

\begin{abstract}
Kivonat
A szúbogarak (Curculionidae, Scolytinae) egyes fajai, különösen fenyőerdőkben, a legveszélyesebb erdei károsítók közé tartoznak. A legtöbb szúfaj általában nem támad meg, nem pusztít el egészséges fákat, hanem a legyengült egyedeket, valamint az elpusztult fákat kolonizálja sikeresen. Egyes fajok azonban bizonyos abiotikus tényezők hatására (tartósan meleg és száraz időjárás, széltörés, hótörés) tömegesen elszaporodhatnak, így gazdasági és ökológiai hatásuk jelentős. A bogarak táplálkozásában, a gazdanövény sikeres kolonizálásában, a gradációjukban fontos szerepet játszanak a szúkkal társult mikroorganizmusok, mint például gombák és baktériumok. Jelen írás célja ezen mikroorganizmusok a szúbogarak életmódjára, valamint a szúk és tápnövényeik közötti interakcióra gyakorolt hatásának bemutatása. Tesszük ezt egy, a ma reneszánszát élő koncepció, a holobiont elmélet szerinti megközelítéssel, vagyis a szúbogarakat és a velük társult mikrobiótát egységes egészként értelmezve.
\end{abstract}

Kulcsszavak: Scolytinae, mikroorganizmusok, szimbiózis, holobiont

\section{THE ROLE OF MICROORGANISMS IN THE ECOLOGY OF BARK BEETLES (CURCULIONIDAE, SCOLYTINAE)}

\begin{abstract}
Some bark beetle species (Curculionidae, Scolytinae), especially in coniferous forests, are major factors for mass mortality of trees. Although bark beetle species usually do not attack healthy trees, they can colonize weakened or dying trees. Some species may have massive outbreaks, especially under defined abiotic conditions (like hot and dry weather or after wind and snow damage) and can have significant economic and ecological effect. Microorganisms associated with bark beetles such as fungi or bacteria play important roles in their colonization success, development, and gradation. This paper provides a review on the effects of microorganisms on the biology of bark beetles and interactions between bark beetles and their host plants. We present these interactions based on the holobiont theory, i.e., considering bark beetles and their associated microbiota as a whole.
\end{abstract}

Keywords: Scolytinae, microorganisms, symbioses, holobiont 


\section{BEVEZETÉS}

A fatest, mint táplálékforrás a legtöbb élőlény számára csak nehezen, vagy egyáltalán nem hasznositható. Ennek legfőbb oka a növényi sejtfalat felépítő cellulóz és lignin kémiai stabilitása, melyek lebontásához speciális enzimek szükségesek. A növények számos védekező mechanizmussal alkalmazkodtak a kórokozók és károsítók támadásával szemben. Ilyen adaptációnak tekinthető többek között a hiperszenzitív reakció, a káros szervezetekre toxikus vegyületek termelése, illetve fás szárú növények esetén a kéreg, mint fizikai akadály. A rovarok és kórokozók alkalmazkodtak e nehézségekhez, esetenként igen sikeresen. A szúbogarak esetében a tápnövényhez való adaptációban kulcsszerepet játszanak a velük szimbiózisban élő mikroorganizmusok, amelyek nem csupán előnyöket biztosítanak a bogaraknak, de jelenlétük sokszor nélkülözhetetlen létszükséglet is lehet.

A szúkkal társult mikroszervezetek, különösen a gombák olyan elönyöket biztosítanak, mint például a tápnövény ellenálló képességének csökkentése azáltal, hogy a növény által termelt toxikus vegyületeket semlegesítik, és/vagy annak szállítását megakadályozzák. Ezen gombák különböző mértékben, de növénypatogéneknek tekinthetők, ahol az előbb említett képességek lényeges virulencia faktorok lehetnek (Kirisits 2004, DiGuistini et al 2011). Az egyik legfontosabb szimbiotikus kapcsolat gomba és szú között a táplálkozásbiológiai kapcsolat. Ennek iskolapéldája a fatestben fejlődő ambrózia bogarak és az úgynevezett ambrózia gombák kapcsolata. Ezek a szúfajok a faanyagot csak szubsztrátnak használják, amelyen gombapartnereiket „termesztik” és azok micéliumait, illetve konídiumait fogyasztják. Vannak továbbá olyan háncsban fejlődő fajok is, melyek a kambium és háncs mellett gombapartnereikkel is táplálkoznak (Harrington 2005). Egyes gombák és baktériumok esetében kimutatták, hogy azok szú-feromonokat szintetizálnak, így hatással vannak a bogarak kémiai ökológiájára (Kirisits 2004; Raffa et al 2015). Felfedeztek olyan gombafajokat is, melyek védelmet nyújthatnak rovarpatogén, illetve egyéb antagonista gombákkal szemben (Kirisits 2004, Davis \& Hofstetter 2011). A szúk azonban nem csupán gombákkal élhetnek szimbiózisban, hanem baktériumokkal is (Six 2013). Az elmúlt néhány évtizedben számos kutatást végeztek a szúk és baktériumok közötti interakciókkal kapcsolatban. Bebizonyosodott, hogy egyes baktériumok olyan hasonló vagy azonos szereppel bírnak, amiket eddig csak a szimbióta gombapartnereknek tulajdonítottak (García-Fraile 2017).

Írásunk célja a szúbogarak példáján keresztül bemutatni, hogy az erdei életközösségekben fellépő károsítások mögött rendkívül összetett folyamatok és összefüggések rejlenek. A szú-mikroba kapcsolatok gyakorisága, és a fent említett ökológiai szerepek alapján elmondható, hogy a mikroorganizmusok meghatározó elemei a bogarak biológiájának. Igen gyakran fontos mediátor szerepet töltenek be a szúk és azok tápnövényei közötti interakciókban, így e kölcsönhatások jobb megértése érdekében nem hagyhatók figyelmen kívül. Érdemes lehet ezeket a szú-mikroba rendszereket egy egységes egészként, vagyis holobiontként szemlélni.

\section{A SZIMBIÓZISTÓL A HOLOBIONT ELMÉLETIG}

Aszimbiózist gyakran úgy határozzák meg, mint kétorganizmus kölcsönösen előnyös együttélése. Valójában ez a mutualizmus definíciója, ami a szimbiózis szűkebb értelmezése, pontosabban annak egyik formája. A szimbiózis fogalmát először de Bary (1879) vezette be, amit két különböző faj együttéléseként határozott meg. Frank (1877) - de Bary-t megelőzően - már leírta ezt a jelenséget, mint szimbiotizmus. Szerinte minden olyan esetet, melyben egy faj egy másikon vagy másikban él - a puszta koegzisztenciájuk alapján, figyelmen kívül hagyva a két fél szerepét -, célszerü szimbiotizmusnak tekinteni. A klasszikus definíció(k) tehát nem beszélnek előnyökről vagy hátrányokról, így szimbiózisnak tekinthetjük a kölcsönösen előnyös együttélésen túl (mutualizmus), a kommenzalizmust, a neutralizmust, a predációt, a parazitizmust, parazitoidizmust és az antagonizmust is. Az egyik legnépszerübb szimbiózis definíciót Zook (1998) fogalmazta meg, miszerint a 
szimbiózis egy organizmus egy vagy több más organizmussal kialakitott és fenntartott kapcsolata, mely új struktúrák és metabolizmus kialakulásához vezet. A szimbiózis kutatás legnagyobb mérföldköve az eukarióta sejt szimbiogenetikus eredetének igazolása volt (Margulis 1970), melynek hatására a témakör a tudományos érdeklődés homlokterébe került. Joggal merül fel a kérdés: ha az evolúció során olyan rendkívül fontos esemény, mint az eukarióta sejt kialakulása egymástól független prokarióták szimbiózisának eredménye, akkor milyen más organizmus evolúciójában lehet még lényeges szerepe a szimbiózisnak? A válasz az, hogy a szimbiózis az evolúció egyik legnagyobb hajtóereje, különösen a magasabb rendü eukarióták (állatok, növények) esetén, melyek döntő többsége szimbiózisban él valamilyen mikroorganizmussal (Gilbert et al 2012, Zook 2015).

A szárazföldi edényes növények mintegy 85-90\%-a valamilyen formában mikorrhiza gombákkal él szimbiózisban, mely kapcsolat nagy valószínűséggel kulcsszerepet játszhatott a szárazföldi növényzet kialakulásában (Feijen et al 2018, Strullu-Derrien et al 2018). A mikorrhiza gombákon túl a gümőképző, nitrogén-fixáló baktériumok is közismert példái a növény-mikroba szimbiózisoknak (Sprent 2005). Az állatok evolúciójára szintén jelentős hatást gyakoroltak a mikrobiális szimbióták. A növényevő rovarok esetén ezek a szimbióták erősen befolyásolták a különféle tápnövényekhez való alkalmazkodást. llyenek például azok a tápcsatornában élő baktériumok, melyek a növényi szövetek emésztését segítik elő (Janson et al 2008, Joy 2012, Six 2013).

A növények és állatok szimbiózisa mikroorganizmusokkal általános jelenség. Ez a felismerése vezetett a holobiont elmélet megfogalmazásához. A holobiont mint fogalom Margulis és Fester (1991) nevéhez kötődik, amit úgy definiáltak, mint a magasabb rendű eukarióta (gazda) és a vele szimbiózisban élő mikroorganizmusok összessége (mikrobióta). Elgondolásuk szerint a holobiont egységes metaorganizmusként müködik, melyben a szimbiózis az evolúció fő hajtóereje. Ebből az elgondolásból bontakozott ki Zilber-Rosenberg és Rosenberg (2008) által kidolgozott hologenom szemléletű evolúció, miszerint a természetes szelekció alanya a holobiont, melynek a teljes genetikai állománya, azaz a hologenom hatékonyabban és gyorsabban képes alkalmazkodni a változó környezeti feltételekhez, mint a makroszkópikus gazdaszervezet önmagában.

A multiszimbiotikus rendszerek a fajok közötti interakciók csaknem teljes spektrumát lefedik. Előfordulnak obligát, fakultatív és véletlenszerü kapcsolatok, valamint a gazda és mikrobióta közötti kapcsolatokon túl, az egyes mikrobák közötti interakciók is meghatározóak lehetnek (Zook 2015). Egy adott holobiont vizsgálatakor kétféle megközelítést célszerű alkalmazni. Az egyik, az egyes mikroba populációk és a gazda közötti kapcsolatok meghatározása, a másik a mikrobák közötti kölcsönhatások vizsgálata. Egy mikrobiótában előfordulnak olyan szimbióták, melyek önmagukban nem, de közösen képesek előnyökhöz juttatni a gazdaszervezetet, mégpedig úgy, hogy kollektív anyagcsere fenntartásával hasznos metabolitokat szintetizálnak (vitaminok, aminosavak). Az egyes mikroorganizmusok egymással kompetitív kapcsolatban is lehetnek, ezzel szabályozva egymás populációját. Ezek alapján a mikrobióta hatása a gazdaszervezetre az egyes mikroorganizmusok közötti kölcsönhatások eredő hatásaként is értelmezhető, így egyes szakirodalmakban nem az egyes szimbióták és a gazda, hanem a mikrobióta mint komplett életközösségközösség és a gazda közötti kapcsolatot nevezik mutualizmusnak (Mushegian \& Ebert 2016). Ezek szerint a gazdaszervezet szempontjából káros szervezetek is ennek a mikrobaközösségnek a szerves részei. Abban az esetben, ha a gazda tolerálja ezek jelenlétét, akkor bizonyos feltételek mellett hasznosnak is tekinthetőek. Ahhoz, hogy a mikrobióta a gazdaszervezet szempontjából megfelelően müködjön, nem csak a diverzitás, hanem az egyes mikrobatörzsek egymáshoz viszonyított aránya és kapcsolatuk hosszútávú fennállása is lényeges, vagyis a mikrobiótának (a gazda közreműködésével) fenn kell tartania egy homeosztatikus állapotot.

A mutualista kapcsolatok tekintetében meg kell említeni, hogy erősödik az a nézet, miszerint a valódi mutualizmus a ritkább eset, és elsősorban az intracelluláris endoszimbiótákra korlátozódik. Az esetek nagy részében a szimbiózis a gazda számára fontos, vagy akár nélkülözhetetlen. A szimbióta mikroorganizmusok többsége a gazdaszervezettől függetlenül is életképes lehet. Sok esetben a gazdának előnyös anyagcseretermékeket a mikroorganizmusok saját céljainak megfelelően állítják elő. A feleslegben termelt metabolitokat a 
gazdaszervezet képes hasznosítani. llyen esetben a kapcsolatot célszerübb lehet facilitációnak tekinteni (Zook 2015, Mushegian \& Ebert 2016).

A holobiont elmélet nagy népszerüségének ellenére széles körben vitatatott. Vannak olyan nézőpontok is, miszerint a gazdaszervezettel társult mikrobiótát környezeti faktornak kell tekinteni, hiszen mikrobák tengerében élünk, és a társult mikroorganizmusok nagy része a gazdától függetlenül is életképes, továbbá egyes szelekciós hatások csak a gazdára, vagy csak a mikrobiótára, illetve annak egyes elemeire hatnak (Mushegian \& Ebert 2016, Douglas \& Werren 2016). Jelen írásnak nem célja eldönteni ezt a tudományos vitát, azonban elmondható, hogy ez az elmélet a bizonytalansága ellenére egy holisztikus szemléletet tükröz. A megközelítés ésszerünek bizonyul, hiszen az élő szervezetek természetes körülmények között nem izoláltan léteznek, hanem egy olyan környezetben, ahol vannak biotikus és abiotikus faktorok, melyek az adott élölény létét és tulajdonságait alapvetően meghatározzák.

\section{A SZÚBOGÁR HOLOBIONT}

A holobiont kutatások népszerü alanyai a rovarok, melyek az állatvilág legnagyobb sokféleséggel bíró képviselöi és szinte kivétel nélkül mindegyik társul valamilyen mikroorganizmussal (Guerrero et al 2013). Ez alól a szúbogarak sem kivételek, sőt gazdasági jelentőségük miatt igen intenziven kutatott ez a rendszertani csoport.

\section{Mikrobiális diverzitás}

A szúbogarak igen változatos mikrobaközösségel élnek szoros kapcsolatban. Ebben a közösségben a bogarak testén és belsejében egyaránt előfordulnak gombák, baktériumok, vírusok, sőt algák is (utóbbiak jellemzően a kutikulán). A legrégebben kutatott és leginkább ismert csoport a szúkkal társult gombák. A szú mikobiótában egyaránt vannak fonalasgombák és élesztögombák (egysejtü növekedésü) (Hofstetter et al 2015).

A legismertebb gombái ennek a szimbiotikus rendszernek az ún. ophiostomatoid gombák, melyek elsősorban fenyőfélék szijácskékülését okozzák (Kirisits 2004). Az ophiostomatoid gombákat az Ascomycota törzs két különböző rendjébe sorolják. A Ceratocystis és Endoconidiophora nemzetségek és anamorf nemzetségeik (Thielaviopsis, Chalara) a Microascales rendbe tartoznak. Az ide tartozó gombák többsége lágyszárú növények kórokozója, de vannak fás szárúakat megbetegítők is. Például a Ceratocystis fagacearum (Hunt, 1956), amely a tölgyek hervadásos megbetegedését okozza (elsősorban Észak-Amerikában) vagy az Endoconidiophora polonica (de Beer et al, 2014) [korábbi nevén Ceratocystis polonica (Moreau, 1952)] lucfenyőn. Ezek a gombák lazább kapcsolatban állnak a szúbogarakkal, többségük inkább rovaroktól független életmódot folytat (Kirisits 2004, de Beer et al 2014). Az ophiostomatoid gombák másik csoportja az Ophiostoma, Grosmannia és Ceratocystiopsis nemzetségek, valamint ezek anamorf nemzetségei a Pesotum, Sporothrix, Hyalorhinocladiella és Leptographium az Ophiostomatales rendbe tartoznak. Ezek a fajok jobban adaptálódtak a szimbióta életmódhoz (Zipfel et al 2006, Hofstetter et al 2015). Az Ascomycota törzs egyéb fonalas képviselöit is gyakran izolálták a szúbogarak mikobiótájából. Ilyenek például az Aspergillus, Penicillium, Tirochoderma, és Mucor fajok, azonban ezek nem állnak szoros kapcsolatban a szúkkal, hanem a pusztuló fa mikrobiális szukcessziójának elörehaladott állapotában megjelenő szaprotrófok (Kirisits 2004).

Az élesztőgombák a legnagyobb mennyiségben jelen lévő mikroorganizmusok a szú mikrobiótában. Tömegességük messze meghaladja mind a fonalasgombákét, mind a baktériumokét. Igen gyakran izolálhatóak a szúk járataiból, bábkamráiból, minden fejlődési stádiumban a kutikuláról, a középbél epitéliumáról és a hemolimfából, valamint a szúk speciális szervéből a micetangiumból is. Szerepükre sokáig csak teoretikus alapokon lehetett következtetni (sok esetben még ma is), ám az utóbbi néhány évtizedben igazolták, hogy a 
szimbiótaélesztőgombákjelentősen befolyásolják más mutualista és antagonista gombapartnereknövekedését, illetve szú-feromonok elöállitásával hatással vannak a szúk kémiai ökológiájára is. Leggyakrabban izolált nemzetségek a Pichia, Ogatea, Kuraishia, és a Candida (Six 2003, Kirisits 2004, Hofstetter et al 2015).

A bazídiumos gombák ritkábban társulnak szúbogarakkal. Az egyetlen nemzetség, amelynek táplálkozásbiológiai szerepe néhány észak-amerikai szúfaj esetén igazolt, a Corticiaceae családba tartozó Entomocorticium. Ezek a gombák jellemzően farontók (Harrington 2005). Europában a betűzőszú [Ips typographus (L., 1758)] járataiból gyakran izolálták a Gloeocystidium ipidophilum (Siemaszko, 1939) nevü gombát, de kapcsolata a szúval még nem tisztázott (Kirisits 2010). További más bazídiumos gombákat is izoláltak [többek között a gyökérrontó tapló, Heterobasidion annosum (Brefeld, 1888) spóráit], de ezek csak véletlenszerủ előfordulásoknak bizonyultak, illetve előfordultak egysejtü növekedésű fajok, amelyek feltehetöleg mikoparaziták (Kirisits 2004).

A legújabb kutatások szerint, a gombák mellett a baktériumok is jelentős szerepet játszanak a szúbogár holobiontban (García-Fraile 2018). Összevetve más gerinctelenekkel a szúk tápcsatornájában élő baktériumok fajszáma azonban jóval alacsonyabb. Az emésztőrendszeren túl a szúbogarak testfelületéről is nagy mennyiségben lehet baktériumokat izolálni, valamint a rézmetszőszú [Pityogenes chalcographus (L., 1761)] petefészkének szöveteiből, sőt egyes fajok (Dendroctonus spp.) micetangiumából is sikerült kimutatni őket. Jellemző baktérium nemzetségek a Rahnella, Bacillus, Chryseobacterium, Acinetobacter, Enterobacter, Klebsiella, Pantoae, Pseudomonas, Serratia, Streptomyces, Erwinia, Aerogenes. Több szúfajból [Ips typographus, Xylosandrus germanus (Hoffmann, 1941), Pityogenes chalcographus, Coccotrypes dactyliperda (Eichoff, 1878) és Hypothenemus hampei (Wood \& Bright, 1992)] izoláltak Wolbachia fajokat is, amelyekröl igazolták, hogy hatással vannak az említett szúfajok ivararányára és szaporodásbiológiára (Hofstetter et al 2015). Ez a felfedezés a szúbogarak elleni védekezés egy egészen új irányát nyitotta meg.

\section{Adaptáció a szimbiózishoz}

Zook (1998) szerint egy szimbiotikus kapcsolat új struktúrák kialakulását eredményezi. Szúbogarak esetén ez a micetangium. A fogalmat elöször Batra (1963) vezette be eredetileg mikangium néven, de a jelenlegi terminológia szerint a micetangium a helyes megnevezés (Vega \& Biedermann 2020). Micetangiumnak tekinthető minden olyan képlet, amely biztosítja a társult gombapartner(ek) szállitását, védelmét és a szimbiotikus kapcsolat fenntartását. Ezek elsősorban a kültakaró módosulásai, bemélyedései, melyek igen gyakran mirigyekkel vannak összeköttetésben. A mirigyek szekrétumai megvédik a spórákat a kiszáradástól, az UV sugárzástól és bizonyos esetekben táplálják is azokat. Sok faj esetében nincs, vagy nem igazolt a micetangium jelenléte. A micetangiumot több szempont szerint lehet csoportosítani. llyen szempontok például, hogy hol fordul elő a bogár testén, milyen a felépítése, van-e kapcsolata mirigyekkel, és ha igen, milyen szekrétumot választ ki (Kirisits 2004). A micetangium típusa faji bélyeg, és változatossága miatt nehéz is kategorizálni. A tipizálást tovább nehezíti, hogy sokan csak azokat a típusokat tekintik valódi micetangiumnak, melyek egyértelműen mirigysejtekkel vannak összeköttetésben. Ugyanakkor vannak olyan esetek is, ahol nem igazolták, vagy nem is vizsgálták a feltételezett micetangium ultrastruktúráját és kapcsolatát mirigysejtekkel, azonban konzisztens módon nagy számban tartalmaz gombaspórákat. Ebből a megfontolásból most Six (2003) tipológiáját mutatjuk be, amely három fö típust különít el. A legfejlettebb típus a zsák vagy zseb típusú micetangium (sac mycetangium), elsősorban a fatestben fejlődő ambrózia bogarakra jellemző (pl.: Xyleborini nemzetség). A második típus a „setal brush mycetangium”, amely a bogár testének szőrrel sürün borított bemélyedö, vagy nem bemélyedő régiója, mint például a Pytioborus fajok nőstényeinek micetangiuma. A harmadik típus az üreg típusú micetangium (pit mycetangium). Ide tartozik minden olyan bemélyedés, amely spóra repozitóriumként funkcionál. Ezek lehetnek a nyakpajzson és a szárnyfedőkön, mint például a hatfogú szúnál [Ips sexdentatus (Börner, 1776)], ahol a mirigysejtek jelenlétét is igazolták, illetve a kis 
fenyőbélszú [Tomicus minor (Hartig, 1834)] esetében a szárnyfedő varratának elülső szakasza is feltehetőleg micetangiumként funkcionál. Six (2002) ezeket a kategóriákat további alkategóriákra osztja aszerint, hogy a micetangium igazoltan mirigyes, vagy sem (glandular/nonglandular mycetangium) (Lévieux et al 1991, Six 2003, Harrington 2005).

A gombák (elsősorban az ophiostomatoid gombák) morfológiailag szintén alkalmazkodtak a szimbiózishoz. Ilyen morfológiai adaptáció a gomba hosszú nyakú ivaros termőteste (peritécium). A peritécium belsejében képződő aszkuszok fala hamar feloldódik és a nyálkás spóratömeg (cirrusz) a nyak nyílásán (oszciólum) keresztül csepp formájában jelenik meg. A peritécium nyaka a szú járat falából hosszan kinyúlik, így az ott áthaladó bogarat gyakorlatilag „beoltja” spórával. Egyes ophiostomatoid gombák aszkospóráit gyakran borítja nyálkás tok, amely a bogár testén való megtapadást segíti, továbbá önmagában is képes védelmet biztosítani a káros környezeti hatások ellen (UV sugárzás, kiszáradás), így nincs feltétlenül szüksége a bogár eredetü szekrétumra. Ennek a toknak köszönhetően a spórák a bogarak emésztőrendszerében is életképesek maradhatnak, így a tápcsatorna is fontos spóra rezervoár lehet (Kirisits 2004). Az ambrózia gombák és ambrózia bogarak esetén érdemes megemlíteni, hogy a nagyméretü, tápanyagban gazdag spóra szintén a szimbiózishoz való adaptációra utal (Harrington 2005).

\section{A szimbióták táplálkozásbiológiai szerepe}

A szúbogarak táplálkozásbiológiai szempontból meglehetősen változatos csoportot jelentenek. Tulajdonképpen minden növényi szövethez adaptálódtak szúfajok. Egyesek a hánccsal és kambiummal táplálkoznak, más fajok spermatofág (mag, illetve termés fogyasztó) táplálkozásúak, de vannak lágyszárú növények szöveteit és gombákat fogyasztó fajok is, valamint ezen kategóriák átmenetei (Kirkendall et al 2015). Ebben a fejezetben az erdészeti szempontból fontosabb floeofág, floeomicetofág és xilomicetofág fajok mutatjuk be. A floeofág fajok a hánccsal és kambiummal táplálkoznak, míg a xilomicetofág fajok a magukkal hurcolt gombapartnerekkel. A floemicetofág fajok átmenetet képeznek a xilomicetofág és a floeofág fajok között. Képesek tisztán a hánccsal táplálkozni, de kiegészítésképpen gombapartnereikkel is, ami a rendelkezésre álló tápanyagok hatékonyabb kihasználását eredményezi. Ilyen fajok Európában a Tomicus minor és az Ips acuminatus (Gyllenhal, 1827) (Kirisits 2004, Kirkendall et al 2015).

A fás szövetek meglehetősen szegényes, nehezen hasznositható táplálékforrásnak tekinthetők. A két legfontosabb biogén elem a nitrogén és a foszfor - melyek nélkülözhetetlenek a növekedéshez és a szaporodásához - csak limitált mennyiségben van jelen bennük. Bár a két elem koncentrációja rendkívül alacsony, azonban egy faegyed teljes biomasszája a bogarak számára elegendő mennyiségben tartalmazza ezeket (Six 2012). Ehhez a környezethez a floeofág szúk úgy alkalmazkodtak, hogy testtömegük többszörösének megfelelő mennyiségü háncsot fogyasztanak el fejlődésük során, míg a floeomicetofág, és xilomicetofág fajok esetén, a társult gombák biztositják a szükséges mennyiségű nitrogént és foszfort. A gombák behálózzák a háncs és a szíjács szöveteit, ahonnan az elemeket a szú közvetlen környezetébe szállítják és felhalmozzák, ezzel lokálisan jelenős mértékben megnövelik a nitrogén és foszfor koncentrációját (Harrington 2005, Six \& Elser 2019). Egyes szúfajok nitrogén ellátásában a bakteriális szimbióták is fontos szereppel bírnak. A Dendroctonus valens (LeConte, 1859) tápcsatornájában élő Raoultella terrigena (Drancourt et al 2001) baktérium esetében sikeresen szekvenálták a nifH és nifD géneket, melyek a nitrogén-fixációhoz szükséges enzimeket kódolják. A bogár tápcsatornájában jelen lévő Pseudomonas fluorescens (Migula, 1895), Serratia proteomaculans (Grimont et al, 1978) és Rahnella aquatilis (Izard et al, 1981) baktériumok pedig képesek a húgysavat nitrogén- és szénforrásként hasznosítani, kvázi újrahasznosítják a bogár eredetű anyagcsere végterméket (Morales-Jiménez et al 2013).

Az ophiostomatoid és az ambrózia gombák nem képesek a növényi sejtfal fő komponensei, a cellulóz és a lignin bontására, azonban a parenchima sejtekben található tartalék szénhidrátokhoz könnyedén hozzáférnek. 
A szénhidrátokat a nitrogénhez és a foszforhoz hasonlóan szintén a szúk számára akkumulálják, ami a xilomicetofág szúk számára létfontosságú. A háncs nagyobb mennyiségben tartalmaz egyszerủ szénhidrátokat, amelyek a floeofág szúk szükségleteit kielégíti, a floeomicetofág fajok esetén pedig többlet szénhidrátot jelent (Kirisits 2004, Harrington 2005). Érdemes megemlíteni a Dendroctonus brevicomis (LeConte, 1876) micetangiális szimbiótájának egy Entomocorticium fajnak celluláz és lakkáz aktivitását. A gomba képes bizonyos mértékü cellulóz, és ligninbontásra, ennek köszönhetően a juvenilis bogarak a kéregben lévő szénhidrátokhoz is hozzáférnek (Six 2019). A Dendroctonus fajok tápcsatornájában élő Streptomyces fajok esetén szintén kimutattak cellulózbontást (Hulcr et al 2011). A szénhidrátok bontásával kapcsolatban nagyon izgalmas a kávészú (Hypothenemus hampei) esete. A kávébabban található galaktomannán bontásához szükséges enzim génjéről kimutatták, hogy horizontális géntranszfer útján egy szimbióta baktériumból épült be a szú genomjába (Acuna et al 2012). Ez az eset a holobiont elméletet erősíti.

A szúbogarak növekedéséhez, átalakulásához és szaporodásához szükséges hormonok szintetizálásához nagy mennyiségben igényelnek szterolokat, mint a hormon molekulák prekurzorait. A növényekben található fitoszterolok egyrészt nagyon alacsony koncentrációban vannak jelen, másrészt azokat a bogarak nem tudják hasznosítani. A szimbióta gombák viszont nagy mennyiségben tartalmaznak ergoszterolt. Az ergoszterol már hasznosítható szterolforrás a bogarak számára (Six 2012). Ennek segítségével elő tudják állítani a fajtársak csalogatásához szükséges feromonokat.

\section{A tápnövény védelmének leküzdése: patogenitás és detoxifikáció}

A tápnövény (jelen esetben fenyőfélék) a szúbogarak támadása ellen egy sor kémiai és mechanikai védelmi rendszerrel rendelkezik.

A szú befurakodására a növény nagy mennyiségű gyantatermeléssel reagál, melybe a bogár beleragadhat. A gyantában nagy mennyiségben találhatóak terpén és fenolvegyületek, melyek a bogarakra és egyes mikroorganizmusokra toxikusak (Krokene 2015). A szúk alapvetően háromféle stratégiát fejlesztettek ki ezekkel szemben. Az egyik a szoliter stratégiai. A Dendroctonus micans (Erichson, 1836) például magányosan támadja meg a fát, mondhatni a fa ingerküszöbe alatt ténykedik, így nem indukál nagy mennyiségü gyantatermelést. A másik ilyen stratégia a tömeges támadás, mely során a nagy mennyiségü bogár szimultán támadásának hatására a fa védelme gyakorlatilag kimerül. Ilyen faj például Európa legagresszívebb szúfaja, a betűzőszú (Ips typographus), valamint Észak-Amerikában a Dendroctonus ponderosae (Hopkins, 1902). A harmadik stratégia a szimbiótákkal való kooperáció, melynek során a bogarak magas virulenciájú növénypatogén gombákat hurcolnak magukkal.

A korábban már ismertetett ophiostomatoid gombák többsége alacsony virulenciájú, vagy avirulens, ezért csak nagy mennyiségü inokuláció hatására okoznak betegséget (pl.: tömeges támadáskor). Az avirulenciát, illetve hipovirulenciát feltehetőleg egy duplaszálú RNS mikovírus okozza, de ez a vírus nem minden populációban van jelen (PI.: Cryphonectria parasitica és az ellene való védekezés szelídgesztenyén). A magas virulenciájú fajok közül a legismertebb, a szilek hervadásos pusztulását okozó Ophiostoma ulmi (Nannfeldt, 1934), illetve Ophiostoma novo-ulmi (Brasier, 1991). Mindkét faj a Scolytus scolytus (Fabricius, 1775) szúfajhoz társul (Kirisits 2004). Lucfenyőn virulens faj az Ips typographus-hoz kötődő E. polonica. Pinus fajokon a Dendroctonus ponderosae a Grosmannia clavigera (Zipfel et al 2006) fajjal, míg a Tomicus piniperda (L., 1758) a gyökérbetegséget okozó Leptographium wingfieldii (Morelet, 1988) fajjal él szimbiózisban (Yamaoka 2017). Nagyon sokáig úgy vélték, hogy a háncsban fejlődő szúfajokkal társult patogén gombák nélkülözhetetlenek a fa sikeres kolonizációjához és elpusztításához. Ezt az elgondolást sokan cáfolják. Számos kutatási eredmény alapján elmondható, hogy az olyan agresszív fajok, mint az l. typographus és a $D$. ponderosae patogén gombák nélkül is sikeresen legyőzik a fa ellenálló képességét (Six \& Wingfield 2011). Ugyanakkor az agresszív szú és a vele társult patogén gomba egymás hatását additív vagy szinergikus módon erősítheti (Krokene 2015). 
A terpenoidok és fenolos vegyületek lebontását a $G$. clavigera és az $E$. polonica esetében igazolták, sőt az is kiderült, hogy a két gomba ezeket a vegyületeket szén és energiaforrásként is képes hasznositani. Ezeket a mechanizmusokat még nem ismerjük teljesen, a komplett reakcióutakat még csak részben írták le (Lah et al 2013, Wadke et al 2016).

Hasonló detoxifikációs funkciókat írtak le baktériumok és élesztőgombák esetén is. llyen baktériumok a D. ponderosae-val szimbiózisban élö Serratia, Rahnella és Brevundimonas fajok (Boon et al 2013). Továbbá a Dendroctonus brevicomis-szal társult Ogataea pini (Yamada et al, 1995) élesztögomba detoxifikációs aktivitását is igazolták (Davis \& Hofstetter 2011). Az egyes gombák és baktériumok csak néhány vegyületet képesek semlegesíteni. A holobiontokat vizsgálva kiderült, hogy a különböző mikroorganizmusok más-más vegyületet, vegyületcsoportot képesek semlegesíteni, vagyis ezek a mikrobák egymás hatását kiegészitve, egy szélesebb hatásspektrumú detoxifikációt biztositanak a gazdának (Six 2013).

\section{Védelmi funkciók}

A szúkkal társult mikrobák nem csupán a toxikus vegyületekkel szemben nyújtanak védelmet, hanem antagonista, illetve patogén gombákkal és baktériumokkal szemben is. Ennek egyik lehetséges módja, hogy a szimbióta partner a szúra káros szervezetekkel szemben antimikrobiális vegyületeket termel. A másik eset, mikor a szimbióták képesek kiszorítani a gazda természetes ellenségét az adott élettérből. A Dendroctonus frontalis (Zimmermann, 1868) micetangiális szimbiótái az Entomocorticium sp. és Ceratocystiopsis ranaculosus (Bridges \& Perry, 1987) némi védelmet nyújt a fejlődő lárváknak az antagonista Ophiostoma minus (Hans \& Paul Sydow, 1919) ellen. Az O. minus képes elvonni a tápanyagokat a lárvák környezetéböl, azonban a két mutualista gomba erős kompetítor, így elvonja az erőforrásokat az antagonista gombától, a lárvákat viszont táplálja (Kirisits 2004). Ennek a szúfajnak a micetangiumából izolált Streptomyces baktériumok termelte vegyületek szintén gátolják az O. minus növekedését (Scott et al 2008, Hulcr et al 2011). A D. brevicomis-szal társult $O$. pini élesztőgomba esetében kimutatták, hogy az általa termelt illékony vegyületek gátolják az rovarpatogén Beauveria bassiana (Vuillemin,1912) növekedését, ugyanakkor az 0. pini olyan vegyületeket is termel, amik fokozzák a mutualista Entomocorticium sp. növekedését (Davis \& Hofstetter 2011).

\section{Feromon termelés}

A szúbogarak tömegtámadásának koordinálásában, valamint szaporodásában nagy jelentőséggel bírnak a feromonok. Egyes feromonokat nem csupán a bogarak, hanem a szimbióta mikroorganizmusok is termelhetik. Az Ips paraconfusus (Lanier, 1970) tápcsatornájában élö Bacillus cereus (Frankland \& Frankland, 1887) in vitro körülmények között a Pinus fajok által termelt a-pinént cisz- és transz-verbenollá alakítja át, melyek a fajra jellemző aggregációs feromonok. A D. ponderosae esetében két élesztőgomba az O. pini és a Kuraishia capsulata (Yamada et al, 1994) a cisz- és transz-verbenolt, valamint az Ips typographus-szal társult Kuraishia molischiana (Dlauchy et al, 2005), K. capsulata és Candida nitratophila (Meyer \& Yarrow, 1978) élesztögombák a cisz-verbenolt egy antiaggregációs feromonná, verbenonná alakítják (Leufven et al 1984, Hunt \& Borden 1990). Ez a jelenség, azonban nem minden esetben előnyös, hiszen a szúkra veszélyes paraziták, parazitoidok és predátorok is ezeket az infokemikáliákat használják a bogarak lokalizálásához (Hofstetter et al 2015). Ezekből a példákból is látszik, hogy a gazdanövény-szúbogár-gomba-baktérium-illatanyagok-természetes ellenségek kapcsolat sokkal bonyolultabb annál, hogy mindezt valamennyi szúfajra általánosítva értelmezni lehessen (1. ábra). 


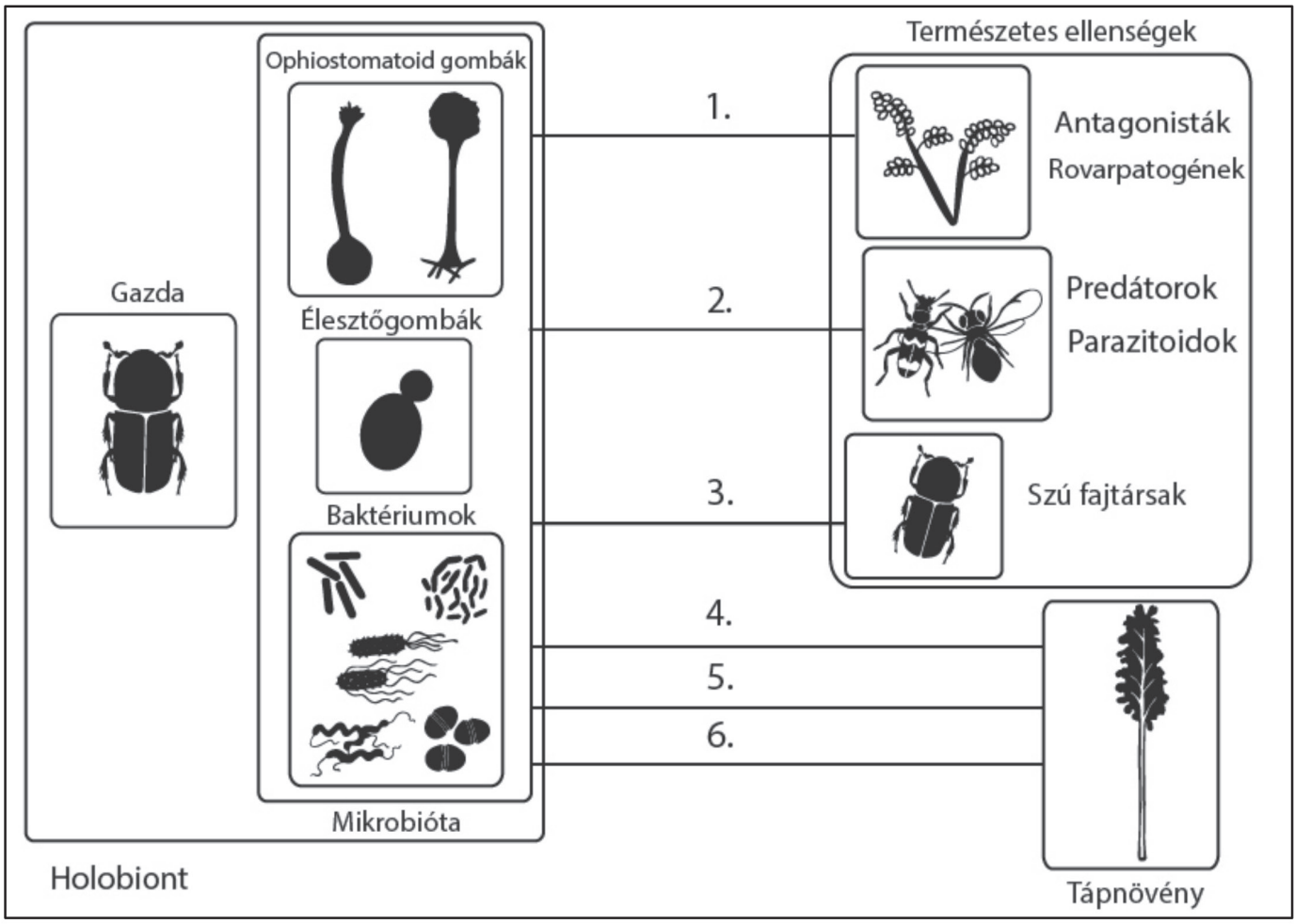

1. ábra: Szúbogarak és a társult mikrobióta interakciói. 1.: Védelem biztositása antagonistákkal és rovarpatogénekkel szemben. 2.: Feromonok csalogató hatása predátorokra és parazitoidokra. 3.: Feromonos kommunikáció a fajtársakkal.

4.: Tápnövénnyel szembeni patogenitás. 5.: Tápnövény által termelt toxikus vegyületek lebontása. 6.: Tápanyagok felvétele a tápnövényböl. (Készítette: Zsidy Emese)

Figure 1: Interactions of microbiota associated with bark beetles 1.: Protection against antagonists and entomopathogens.

2.: Pheromones attracting predators and parasitoids. 3.: Intraspecific pheromone communication. 4.: Pathogenicity on host plant. 5.: Breakdown of toxic compounds produced by the host. 6.: Nutrition uptake from hosts.

(Illustrated by Emese Zsidy)

\section{ÖSSZEFOGLALÁS}

Ebben az áttekintésben igyekeztünk a szúk és mikroorganizmusok közötti szimbiózisokat és azok ökológiai szerepét a lehető legrészletesebben bemutatni. Mindezt abból a megfontolásból, hogy szemléltessük ezen interakciók sokféleségét és jelentőségét. A szúbogarak holobiontjának behatóbb tanulmányozásával és megismerésével mélyebb ismereteket szerezhetünk a szúk biológiájáról, mely tudás új távlatokat nyithat az ellenük való hatékonyabb és természetközeli védekezési stratégiák kidolgozásában. Bár a témában számos publikáció látott napvilágot, mégis meglehetősen keveset tudunk ezekről a szimbiózisokról. A legtöbb szúfaj esetében nem, vagy csak minimális információ áll rendelkezésünkre. A kutatások döntő többsége az agresszív, elsődleges jelleggel károsító szúfajok holobiontját vizsgálja, melyek teljes fajösszetételét, továbbá egyes ismert szimbióta mikroorganizmusok szerepét sem tisztázták még. A legnagyobb nehézsége az ilyen vizsgálatoknak a tenyésztésbe nem vonható mikrobák kimutatása és vizsgálata. A bioinformatika és az új generációs szekvenálási eljárások dinamikus fejlődése jó eséllyel áthidalhatja ezeket a problémákat a jövőbeni kutatások során. 


\section{KÖSZÖNETNYILVÁNÍTÁS}

Jelen publikáció az „EFOP-3.4.3-16-2016-00022 „QUALITAS” Minőségi felsőoktatás fejlesztés Sopronban, Szombathelyen és Tatán" című projekt támogatásával valósult meg. Külön köszönet illeti Zsidy Emesét a kiváló illusztrátori munkájáért.

\section{FELHASZNÁLT IRODALOM}

Acuna R., Padilla B. E., Florez-Ramos C. P., Rubio J. D., Herrera J. C., Benavides P. et al. 2012: Adaptive horizontal transfer of a bacterial gene to an invasive insect pest of coffee. Proceedings of the National Academy of Sciences of the United States of America 109: 4197-4202. https://doi.org/10.1073/pnas.1121190109

Batra L. R. 1963: Ecology of ambrosia fungi and their dissemination by beetles. Transactions of the Kansas Academy of Science 66: 213-236. https://doi.org/10.2307/3626562

Boone C., Keefover-Ring K., Mapes A. C., Adams A. S., Bohlmann J. \& Raffa K. F. 2013: Bacteria associated with a treekilling insect reduce concentrations of plant defense compounds. Journal of Chemical Ecology 39: 1003-1006. https:// doi.org/10.1007/s10886-013-0313-0

Davis T. S. \& Hofstetter R. W. 2011: Reciprocal interactions between the bark beetle-associated yeast Ogataea pini and host plant chemistry. Mycologia 103: 1201-1207. https://doi.org/10.3852/11-083

de Bary A. 1879: Die Erscheinung der Symbiose. Karl J. Trübner, Strassburg.

de Beer Z. W., Duong T., Barnes I., Wingfield B. D. \& Wingfield M. J. 2014: Redefining Ceratocystis and allied genera. Studies in Mycology 79: 187-219. https://doi.org/10.1016/j.simyco.2014.10.001

DiGuistini S., Wang Y., Liao N. Y., Taylor G., Tanguay P., Feau N. et al. 2011: Genome and transcriptome analyses of the mountain pine beetle-fungal symbiont Grosmannia clavigera, a lodgepole pine pathogen. Proceedings of the National Academy of Sciences of the United States of America 108: 2504-2509. https://doi.org/10.1073/pnas.1011289108

Douglas A. \& Werren J. 2016: Holes in the Hologenome: Why host-microbe symbioses are not holobionts. mBio 7: e0209915. https://doi.org/10.1128/mBio.02099-15

Feijen F. A. A., Vos R. A., Nuytinck J. \& Merckx V. S. F. T. 2018: Evolutionary dynamics of mycorrhizal symbiosis in land plant diversification. Scientific Reports 8: 10698. https://doi.org/10.1038/s41598-018-28920-x

Frank A. B. 1877: Über die biologischen Verhältnisse des Thallus einiger Krustenflechten. Beiträge zur Biologie der Pflanzen 2: 123-200.

García-Fraile P. 2018: Roles of bacteria in the bark beetle holobiont - how do they shape this forest pest? Annals of Applied Biology 172: 111-125. https://doi.org/ 10.1111/aab.12406

Gilbert S. F., Sapp J. \& Tauber A. I. 2012: A symbiotic view of life: We have never been individuals. The Quarterly Review of Biology 87: 325-341. https://doi.org/ 10.1086/668166

Guerrero R., Margulis L. \& Berlanga M. 2013: Symbiogenesis: the holobiont as a unit of evolution. International Microbiology 16: 133-143. https://doi.org/10.2436/20.1501.01.188

Harrington T. C. 2005: Ecology and evolution of mycophagous bark beetles and their fungal partners. In: Vega F. E. \& Blackwell M. (eds.): Ecological and evolutionary advances in insect-fungal associations. Oxford University Press, Oxford, 257-291.

Hofstetter R. W., Dinkins-Bookwalter J., Davis T. S. \& Klepzig K. D. 2015: Symbiotic associations of bark beetles. In: Vega F. E. \& Hofstetter R. W. (eds.): Bark beetles: biology and ecology of native and invasive species. Academic Press, London, 209-245.

Hulcr J., Adams A. S., Raffa K. F., Hofstetter R. W., Klepzig K. D. \& Currie C. R. 2011: Presence and diversity of Streptomyces in Dendroctonus and sympatric beetle galleries across North America. Molecular Ecology 61: 759-768. https://doi. org/10.1007/s00248-010-9797-0 
Hunt D. W. A. \& Borden J. H. 1990: Conversion of verbenols to verbenone by yeasts isolated from Dendroctonus ponderosae (Coleoptera: Scolytidae). Journal of Chemical Ecology 16: 1385-1397. DOI: 10.1007/BF01021034

Janson, E. M., Stireman J. O., Singer M. S. \& Abbot P. 2008: Phytophagous insect-microbe mutualisms and adaptive evolutionary diversification. Evolution 62: 997-1012. https://doi.org/10.1111/j.1558-5646.2008.00348.x

Joy J. B. 2012: Symbiosis catalyses niche expansion and diversification. Proceedings of the Royal Society B: Biological Sciences 280: 2820. https://doi.org/10.1098/rspb.2012.2820

Kirisits T. 2004: Fungal associates of European bark beetles with special emphasis on the ophiostomatoid fungi. In: Lieutier, F., Day K. R., Battisti A., Grégoire J. C. \& Evans H. F. (eds.): Bark and wood boring insects in living trees in Europe, a synthesis. Springer, Dordrecht, 185-223.

Kirisits T. 2010: Fungi isolated from Picea abies infested by the bark beetle Ips typographus in the Białowieza forest in north-eastern Poland. Forest Pathology 40: 100-110. https://doi.org/10.1111/j.1439-0329.2009.00613.x

Kirkendall L. R., Biedermann P. H. W. \& Jordal B. H. 2015: Evolution and diversity of bark and ambrosia beetles. In: Vega F. E. \& Hofstetter R. W. (eds.): Bark beetles: biology and ecology of native and invasive species. Academic Press, London, 85-156.

Krokene P. 2015: Conifer defense and resistance to bark beetles. In: Vega F. E. \& Hofstetter R. W. (eds.): Bark beetles: biology and ecology of native and invasive species. Academic Press, London, 177-207.

Lah L., Haridas S., Bohlmann J. \& Breuil C. 2013: The cytochromes P450 of Grosmannia clavigera: Genome organization, phylogeny, and expression in response to pine host chemicals. Fungal Genetics and Biology 50: 72-81. https://doi. org/10.1016/j.fgb.2012.10.002

Leufven A., Bergstrom G. \& Falsen E. 1984: Interconversion of verbenols and verbenone by identified yeasts associated from the spruce bark beetle Ips typographus. Journal of Chemical Ecology 10: 1349-1361. https://doi.org/10.1007/ BF00988116

Lévieux J., Cassier P., Guillaumin D. \& Roques A. 1991: Structures implicated in the transportation of pathogenic fungi by the European bark beetle, Ips sexdentatus Boerner: ultrastructure of a mycangium. The Canadian Entomologist 123: 245-254. https://doi.org/ 10.4039/Ent123245-2

Margulis L. 1970: Origin of eukaryotic cells: Evidence and research implications for a theory of the origin and evolution of microbial, plant and animal cells on the precambrian Earth. Yale University Press, New Heaven.

Margulis L, \& Fester R 1991: Symbiosis as a source of evolutionary innovation: speciation and morphogenesis. MIT Press, Boston.

Morales-Jimenez J., de Leon A.V.P., García-Domínguez A., Martínez-Romero E., Zuniga G. \& Hernandez-Rodríguez C. 2013: Nitrogenfixing and uricolytic bacteria associated with the gut of Dendroctonus rhizophagus and Dendroctonus valens (Curculionidae: Scolytinae). Microbial Ecology 66: 200-210. https://doi.org/10.1007/s00248-013-0206-3

Mushegian A. A.; Ebert D. 2016: Rethinking „mutualism” in diverse hostlsymbiont communities. BioEssays 38: 100-108. https://doi.org/10.1002/bies.201500074

Raffa K. F., Grégoire J. C. \& Lindgren B. S. 2015: Natural history and ecology of bark beetles. In: Vega F. E. \& Hofstetter R. W. (eds.): Bark beetles: biology and ecology of native and invasive species. Academic Press, London, 1-40.

Scott J. J., Dong-Chan O., Yuceer M. C., Klepzig K. D., Clardy J. \& Currie C. R. 2008: Bacterial protection of beetle-fungus mutualism. Science 322: 63. https://doi.org/10.1126/science.1160423

Six D. L. 2003: Bark beetle-fungus symbioses. In: Bourtzis K. \& Miller T. A. (eds.): Insect symbiosis. contemporary topics in entomology series. CRC Press, Boca Raton, London, New York, Washington D.C., 97-114.

Six D. L. 2012: Ecological and evolutionary determinants of bark beetle-fungus symbioses. Insects 3: 339-366. https://doi. org/ 10.3390/insects3010339

Six D. L. 2013: The bark beetle holobiont: why microbes matter. Journal of Chemical Ecology 39: 989-1002. https://doi. org/10.1007/s10886-013-0318-8

Six D. L. 2019: A major symbiont shift supports a major niche shift in a clade of tree/killing bark beetles. Ecological Entomology 45: 190-201. https://doi.org/10.1111/een.12786 
Six D. L., James J. \& Elser J. J. 2020: Mutualism is not restricted to treelkilling bark beetles and fungi: the ecological stoichiometry of secondary bark beetles, fungi, and a scavenger. Ecological Entomology 45: 1134-1145. https://doi. org/10.1111/een.12897

Six D. L. \& Wingfield M. J. 2011: The role of phytopathogenicity in bark beetle-fungus symbioses: a challenge to the classic paradigm. Annual Reviev of Entomology 56: 255-272. https://doi.org/10.1146/annurev-ento-120709-144839

Sprent J. I. 2005: Nitrogen in soils symbiotic fixation. In: Hillel D. (ed.): Encyclopedia of soils in the environment. Elsevier, Amsterdam, 46-56. https://doi.org/10.1016/B0-12-348530-4/00457-4

Strullu-Derrein C., Selosse M. A., Kenrick P. \& Martin F. M. 2018: The origin and evolution of mycorrhizal symbioses: from paleomycology to phylogenomics. New Phytologist 220: 1012-1030. https://doi.org/10.1111/nph.15076

Vega F. E. \& Biedermann P. H. W. 2020: On interactions, associations, mycetangia, mutualists and symbiotes in insect. fungus symbioses. Fungal Ecology 44: 100909. https://doi.org/10.1016/j.funeco.2019.100909

Wadke N., Kandasamy D., Vogel H., Lah L., Wingfield B. D., Paetz C. et al. 2016: The bark-beetle-associated fungus, Endoconidiophora polonica, utilizes the phenolic defense compounds of its host as a carbon source. Plant Physiology 171: 914-931. https://doi.org/10.1104/pp.15.01916

Yamaoka Y. 2017: Taxonomy and pathogenicity of ophiostomatoid fungi associated with bark beetle infesting conifers in Japan, with special reference to those related to subalpine conifers. Myoscience 58: 221-235. https://doi.org/10.1016/j. myc.2017.03.001

Zilber-Rosenberg I. \& Rosenberg E. 2008: Role of microorganisms in the evolution of animals and plants. FEMS Microbiology Reviews 32: 723-735. https://doi.org/10.1111/j.1574-6976.2008.00123.x

Zipfel R. D., de Beer Z. W., Jacobs K., Wingfield B. D., Wingfield M. J. 2006: Multigene phylogenies define Ceratocystiopsis and Grosmannia distinct from Ophiostoma. Studies in Mycology 55: 75-97. https://doi.org/10.3114/sim.55.1.75

Zook D. 1998: A new symbiosis language. Symbiosis News 1: 1-3.

Zook D. 2015: Symbiosis-Evolution's co-author. In: Gontier N. (ed.): Reticulate Evolution. Cham, Switzerland. Springer, 41-80.

Érkezett: 2021. július 14..

Közlésre elfogadva: 2021. szeptember 13. 